\title{
Sobre Tábuas Brutas e Porcelanas Finas
}

\author{
[ About Gross Boards and Fine Porcelains
}

\section{Priscila Matsunaga ${ }^{1}$}

RESUMO O artigo propõe uma reflexão sobre o trabalho da Companhia do Latão, grupo teatral paulistano. O Latão apresenta um repertório de peças teatrais que auxilia na compreensão da formação brasileira e, ao mesmo tempo, das formas representacionais que nos auxiliam na compreensão da realidade. Esboça-se, aqui, o interesse pelos "dramas representativos”, que se fazem a partir do ponto de vista dos trabalhadores. Em específico, analiso a peça $O$ Patrão Cordial, inspirada em Raízes do Brasil, e em O Sr. Puntila e Seu Criado Matti. - Palavras-chave Companhia

Recebido em 22 de julho de 2014

Aprovado em 08 de dezembro de 2014 do Latão, Bertolt Brecht, teatro épico, drama. ABSTRACT The article proposes a reflection on the work of the theater group Companhia do Latão. The group presents plays related to the study of the Brazilian culture and, at the same time, help us to understand the reality. The outline here is related to "representative dramas," from the workers point of view. In particular, I analyze the play O Patrão Cordial, inspired by Raízes do Brasil and Sr. Puntila e Seu Criado Matti. - Keywords Companhia do Latão, Bertolt Brecht, epic theater, drama.

MATSUNAGA, Priscila. Sobre tábuas brutas e porcelanas finas. Revista do Instituto de Estudos Brasileiros, Brasil, n. 60, p. I29-I5I, abr. 2015.

DoI: http://dx.doi.org/Io.II606/issn.23I6-90IX.voi6opI29-I5I

I Universidade Federal do Rio de Janeiro (UFRJ, Rio de Janeiro, RJ, Brasil). 
En un pilar que sostiene el techo del cuarto de trabajo de Brecht están pintadas estas palavras: La verdade es concreta.

En el borde de uma ventana hay un burrito de madera que puede menear la cabeza.

Brecht le há colgado um pequeno cartel em el que ha escrito:

También yo debo entender

Walter Benjamin ${ }^{2}$

No ensaio "A Cordialidade Puntiliana", Anatol Rosenfeld observa que na peça $O$ Sr. Puntila e o Seu Criado Matti, de Bertolt Brecht, "o ébrio bondoso nada é senão um recurso cênico para representar, de um modo hilariante e irônico, a ordem puntiliana que consagra a desordem”. Brecht teria construído uma peça episódica, "sem unidade de ação, continuidade de intriga a desenvolver-se até o desenlace final". A relação com seu motorista "Matti, criado cético, solidário com os seus colegas, que tem a sabedoria e um pouco a esperteza dos oprimidos", é de desconfiança, embora embriagado procure tratá-lo, como os demais empregados, de forma "humanizada". A demonstração da atitude do superior, que não se afigura nem bom ou mau, posto que nos momentos de embriaguez tenda conferir "benefícios ocasionais", é exemplo de uma atitude que, ao final das contas, mantém tudo na mesma. Se não há novidade, segundo Rosenfeld, no tratamento de caracteres contraditórios homem afetuoso quando embriagado e egoísta quando sóbrio - "nova é a maneira de como Brecht aproveita a curiosa duplicidade que desintegra a personalidade do fazendeiro. A partir dela analisa a dialética inerente às relações entre senhor e criado - tão bem exposta por Hegel - e, concomitantemente, procura elucidar certos aspectos da sociedade de classes" 3 .

A comédia inacabada de Hella Wuolijoki que resultou, em I940, em O Sr. Puntila e Seu Criado Matti, sofreu modificações para "realçar a farsa subjacente, desmantelar as conversas psicologizantes e assim ganhar espaço para narrativas da vida popular finlandesa ou para a emissão de opiniões”, que segundo Brecht 
poderiam resultar "numa forma teatral para a contradição "patrão" e "criado" e devolver ao tema sua poesia e comicidade"4.

Brecht estrearia Puntila, segundo Fernando Peixoto, em 5 de junho de I948, em Zurich, no Schauspielhaus, com codireção de Hurt Hirshfeld5. Em suas notas de trabalho, o dramaturgo estabelece um diálogo com o teatro popular da época. Faz recomendações para a construção de um novo teatro popular (utilizar os achados do teatro à forma de revista imprimindo substância épica e realismo; aproveitar do lirismo de grande beleza poética conferindo-lhe maior objetividade e proporcionar, na atuação, um estilo dignificatório, entre artístico e natural) concluindo:

Las recomendaciones precedentes solo se proponen sinalar que la nueva pieza popular tambiéns tiene derecho a ser considerada como um nuevo arte realista. Es um género que há sido desdenado durante mucho tempo y etregado al diletantismo o a la rutina. Es tiempo de fijarle los nobles objetivos a que la obliga su denominación. ${ }^{6}$

Estão claras as bases do trabalho: a nova peça popular também tem o direito de ser considerada como uma nova arte realista. O público frequentador do teatro, acostumado a um teatro popular rude e despretensioso, em que "gracejos grosseiros misturam sentimentalismo com uma moral bárbara e uma sensualidade barata", terá, portanto, em Puntila, a oportunidade de observar, e se divertir, diante de uma figura em desintegração, tirando dela achados que, pela construção de uma nova forma de representação, servirão para compreensão da realidade. Atingido este objetivo, esta é uma arte realista: "em cada caso particular tem de se confrontar a descrição da vida com a própria vida descrita (e não com outra representação)". Os argumentos estão circunscritos pelo debate em torno do Expressionismo do qual Brecht participou ainda que "posteriormente" (textos seus não foram publicados, a propósito de não enfraquecer a unidade da Frente Popular Antifascista, alimentando a polêmica com Lukács). Para Ulrich Merkel, a avaliação do passado expressionista teve dois temas de fundo: a alternativa entre realismo e formalismo - e a necessária compreensão do debate entre os exilados alemães pela ótica do Primeiro Congresso de Escritores Soviéticos -; e a questão do legado cultural da burguesia: "que partes

\footnotetext{
4 BRECHT, Bertolt. Diário de Trabalho, vol. I: I938-I94I. Tradução de Reinaldo Guarany e José Laurenio de Melo. Rio de Janeiro, Rocco, 2002, p. II9.

5 PEIXOTO, Fernando. Brecht Vida e Obra. 2. ed. Rio de Janeiro, Paz e Terra, I974, p. 202. Para a publicação, em I950, Brecht fez alterações no texto. E inclui a Canção de Puntila (música de Paul Dessau) para servir de ligação entre as cenas (junto com o texto foram igualmente publicadas notas de trabalho e um ensaio sobre teatro popular - Brecht definiu o texto como uma "peça popular").

6 BRECHT, Bertolt. Escritos sobre Teatro, Vol. II. Selección de Jorge Hacker. Traducción de Nélida Mendilaharzu de Machain. Buenos Aires, Nueva Vision, I970, p. 60.

7 Idem, Estudos sobre Teatro. Tradução de FIama Pais Brandão. Rio de Janeiro, Nova Fronteira, 2005, p. II3. 80 texto de Bertolt Brecht "O Caráter Popular da Arte e o Realismo" foi traduzido por Carlos Eduardo Jordão Machado em: Um capítulo da História da Modernidade Estética: Debate sobre o Expressionismo. São Paulo, Unesp, I998, p. 265.
} 
deste legado poderiam ser aproveitas, que partes deveriam ser modificadas ou eliminadas?”

Apesar dos muitos matizes individuais, podemos divisar três posições básicas no debate: I) A insistência na continuidade da tradição clássica e no caráter modelar dos romancistas realistas do séc. XIX. Esta posição implicava a condenação do Expressionismo. Seu maior representante foi Lukács; 2) A defesa do Expressionismo, posição representada sobretudo por Ernst Bloch;3) A concepção dialética de tradição e inovação, representada sobretudo por Brecht. Durante o debate, Lukács e Bloch apareciam como os contendores mais importantes [...]. O pensador mais radical nesta polêmica foi Bertolt Brecht. [...] Suspeitava que Lukács era o verdadeiro formalista, já que isolava determinadas formas literárias da sua função social, historicamente variável. Contrariando tal posição, Brecht argumentava que as transformações da própria realidade exigiam novas técnicas de representação. Como vemos, realidade significava para Brecht antes tendência do que estado. A realidade estava em constante revolução.?

Em I938, em O Caráter Popular da Arte e o Realismo, com a concepção nada ortodoxa sobre os procedimentos e modelações que o artista deve pôr em movimento para compreender a realidade, Brecht compreende que não se pode verificar se uma obra é realista ou não apenas pela comparação a outras que por definição são realistas: "não podemos deduzir o realismo a partir de determinadas obras existentes; em vez disso, temos de usar todos os meios, velhos e novos, comprovados e por comprovar, vindos da arte e de outros domínios, para oferecer às pessoas uma realidade que elas possam dominar”o. Assim é que tal compreensão está articulada a uma função e uma dimensão específica sobre o popular: "o nosso conceito de popular refere-se ao povo que não só toma plenamente parte do desenvolvimento histórico, como até o usurpa, força, determina. Temos em vista um povo que faz história, que transforma o mundo e se transforma a si próprio. Temos em vista um povo que luta e, portanto, também o conceito combativo de popular" “não existe apenas o ser popular, mas também o tornar-se popular"12, de tal modo que é compreensível sua defesa quanto à restituição de um lugar nobre para a arte realista-popular. Se a experiência soviética determinou traços explícitos de caráter popular (como as experiências de agitprop) e a experiência alemã contou com Piscator e o próprio Brecht, qual percurso, em breves linhas, podemos registrar na experiência brasileira? As variações em torno do teatro de revista, de circo, de teatro de feira ou de teatro de rua abarcam esta dimensão do caráter popular

9 MERKEL, Ulrich (org.). Teatro e Política: Poesias e Peças do Expressionismo Alemão. Rio de Janeiro, Paz e Terra/Instituto Cultural Brasil-Alemanha, I983, p I8-I9.

Io BRECHT, Bertolt. O Caráter Popular da Arte e o Realismo. In: MACHADO, Carlos Eduardo. Um Capítulo da História da Modernidade Estética: Debate sobre o Expressionismo. São Paulo: Unesp, I998.

II Idem, O Caráter Popular..., op. cit., p. 26I.

I2 Idem, p. 264. 
nas artes cênicas. Como salienta Beti Rabetti ${ }^{13}$, "entende-se que o que no Brasil se costuma realizar e estudar como "teatro popular" ocupa um arco de experiências que espelham tanto leituras políticas, como "folclóricas" ou "tradicionais" e, ainda, predominantemente, e de modo mais problemático, leituras que associam o teatro popular ao teatro “de massa”, “comercial”, de 'entretenimento”. É possível observar que a denominação "teatro popular" em contexto brasileiro não é combativo, nos termos brechtianos, ainda que tenhamos tido um teatrólogo que buscou restituir esta função. Augusto Boal assim define teatro popular: ${ }^{\mathrm{I} 4}$

Um espetáculo de teatro é popular se assume a perspectiva do povo na análise do microcosmo social que aparece no espetáculo - ainda que esse espetáculo seja apresentado para um só espectador, ainda que se trate de um ensaio sem a presença de ninguém, ou ainda que o destinatário desse espetáculo não seja o povo. Pergunta-se: se o destinatário não é o povo, para que fazer esse tipo de teatro? Essa é frequentemente a pergunta (e mais frequentemente ainda a acusação) que se faz aos grupos que pretendem fazer teatro para uma plateia pagante em salas convencionais. Afirma-se que é um teatro popular feito para a burguesia e, portanto, inútil. Se lidarmos com palavras, este raciocínio parece correto. Se lidarmos, porém com realidades, nossas observações diretas mostrarão que não é bem assim. $\mathrm{Na}$ verdade as plateias ditas burguesas - não são formadas exclusivamente nem preponderantemente por burgueses. Incluem também pequeno-burgueses, bancários, estudantes e professores, profissionais liberais etc.; em última análise, gente que pode talvez professar as ideias e a ideologia da burguesia, mas que não compartilha as vantagens que a burguesia desfruta com a exploração que exerce. Compartilha as mesmas ideias porque está submetida aos meios de informação e divulgação que são propriedade da burguesia: jornais, televisão, rádio, universidades etc. Porém, como se trata (talvez na maioria ou em grande parte) de seres sociais híbridos (pensam como burgueses, mas não vivem como burgueses, falam como burgueses, mas não comem como burgueses), as suas convicções políticas são bastante reformáveis e substituíveis. Se esta plateia vê um problema social analisado segundo outra perspectiva que não a das classes dominantes, seu pensamento político e social pode ser enriquecido, e esta riqueza pode transformá-lo qualitativamente ${ }^{\text {I5. }}$.

Vejamos que esta é uma problematização que se faz presente aos artistas que incluem o ponto de vista da classe trabalhadora, mas que supostamente não fazem parte dela. Mas será que esta não é uma armadilha àqueles que precisam

I3 RABETTI, Maria de Lourdes. Teatro e Comicidades 2: Modos de Produção do Teatro Ligeiro Carioca. Rio de Janeiro, 7Letras, 2007, p. I3.

I4 BOAL, Augusto. Técnicas Latino-americanas de Teatro Popular. São Paulo, Hucitec, I979, p 33-34.

I5 A discussão sobre o que é "povo" em Augusto Boal e como isto pode ser compreendido, hoje, como "classe trabalhadora" nos levaria para uma direção que merece mais tempo e dedicação e que deixo para outra ocasião. Para manter a coerência com a citação, no mesmo livro Boal define: "povo inclui apenas aqueles que alugam sua força de trabalho". Idem, p. 25 . 
legitimar seu trabalho, quando detratados? Será o "teatro popular" uma categoria tão flexível que faz menos explicar e mais arrefecer seu aspecto aguerrido num país que, se não tende à folclorização pende à recusa daquilo que é popular? Qual denominação mais apropriada para iniciativas que se fazem a partir do ponto de vista da classe trabalhadora? Teatro político? Tendo essas questões em mente, proponho uma leitura do trabalho desenvolvido pela Companhia do Latão, grupo teatral paulistano conhecido pela forte influência de Bertolt Brecht nos estudos teatrais e teóricos.

A análise de Anatol Rosenfeld, somada às notas de trabalho de Brecht, abre a oportunidade de aproximar, ainda que não nos mesmos termos, a "cordialidade puntiliana" ao "mundo sem culpa" de Memórias de um Sargento de Milícias. A aproximação é produtiva temática e formalmente quanto ao ensaio de Antonio Candido. Somam-se a este fato as consequências tiradas pelo crítico que, ao "estabelecer o valor" do romance, nas palavras de Roberto Schwarz, sugere que nos deixemos embalar por "uma fábula realista proposta em tempo de allegro vivace" Antes de estabelecer o valor da obra brechtiana no repertório teatral brasileiro, é de interesse uma reflexão sobre a encenação do Latão, rebatizada de O Patrão Cordial. A problemática do ensaio de Candido parece dar conveniência analítica sobre o trabalho da Companhia do Latão, quanto à observância da realidade brasileira e sua modelação no campo teatral. Neste sentido, a reflexão buscará iluminar, através da encenação proposta, o assunto perene às encenações e dramaturgia da Companhia, que se coloca como um coletivo teatral crítico ao sistema artístico brasileiro, ainda consciente de uma posição de intervenção relativa. Tal questão parece oportuna por problematizar experiências no campo teatral que se interessam pela imbricação processo social e forma teatral, explicitando os mecanismos pelos quais representações artísticas estão atreladas a visões de mundo e o quanto é proveitoso para o ato crítico compreender as funções das estruturas de representação como portadores de sentidos políticos.

\section{TEATRO POLÍTICO?}

Não é novidade apresentar a Companhia do Latão como um dos grupos em atividade interessados em problematizar o contexto social brasileiro a partir da crítica anticapitalista. Com imensa capacidade articuladora, busca referências em diferentes campos de conhecimento sobre o Brasil e seu sistema cultural através de estudos que são incorporados em seus ensaios teatrais. Muitas vezes é considerado como representante do "teatro político" - que escamoteia, em muitos casos, a desvalorização quanto ao seu trabalho. A afirmação de constituir-se como "teatro político", ainda que verdadeira, não especifica as formas e expedientes artísticos pelos quais o teatro faz política. É preciso compreender as modelações artísticas que, bem ou mal, explícitas ou implícitas, aludem ao aprendizado do

I6 CANDIDO, Antonio. Dialética da Malandragem. In: O Discurso e a Cidade. Rio de Janeiro, Ouro sobre Azul, 2010. 
espectador - e me parece que, quando o teatro é considerado político, há uma compreensão sobre um suposto didatismo prejudicial à fruição artística. Ao que parece, a definição não é feita pelos artistas que fazem teatro político, mas por aqueles que pretendem rechaçá-lo - e que para ele se dirigem como formas políticas de percepção. Recuperando Brecht: "em cada caso particular tem de se confrontar a descrição da vida com a própria vida descrita”. Para o teatro de agitprop, por exemplo, "o olhar penetrante dos trabalhadores atravessa a superfície das imagens naturalistas da realidade"

São de amplo conhecimento os estudos de Brecht sobre a teoria marxista. Pela apresentação do dramaturgo, é possível perceber como a análise da estrutura teatral se assemelha a observação empírica, nos termos marxistas, em contraposição prática a filosofia alemã - no caso da do dramaturgo, em contraposição prática a ideologia dramático-naturalista. Em A Ideologia Alemã, Marx e Engels consideram:

[...] a produção de ideias, de representações, da consciência, está, em princípio, imediatamente entrelaçada com a atividade material e com o intercâmbio material dos homens, com a linguagem da vida real. O representar, o pensar, o intercâmbio espiritual dos homens ainda aparecem, aqui, como emanação direta de seu comportamento material. O mesmo vale para a produção espiritual, tal como ela se apresenta na linguagem da política, das leis, da moral, da religião, da metafísica etc. de um povo. Os homens são os produtores de suas representações, de suas ideias e assim por diante, mas os homens reais, ativos, tal como são condicionados por um determinado desenvolvimento de suas forças produtivas e pelo intercâmbio que a ele corresponde, até chegar às suas formações mais desenvolvidas [...]. Não é a consciência que determina a vida, mas a vida que determina a consciência. No primeiro modo de considerar as coisas [a filosofia alemã de Feuerbach] parte-se da consciência como do indivíduo vivo; no segundo, que corresponde à vida real, parte-se dos próprios indivíduos reais, vivos, e se considera a consciência apenas como sua consciência. Esse modo de considerar as coisas não é isento de pressupostos. Ele parte de pressupostos reais e não os abandona em nenhum instante. Seus pressupostos são os homens, não em quaisquer isolamento ou fixação fantástica, mas em seu processo de desenvolvimento real, empiricamente observável, sob determinadas condições [...]..$^{\text {I8 }}$

Como estas questões contribuem para o debate sobre dramaturgia e teatro? A dramaturgia moderna apresenta a consciência da personagem como um dado, pois se refere a um mundo conformado pelo diálogo, no qual os personagens são circunscritos ao mundo por ele composto. A abordagem naturalista, que possui conexões históricas íntimas com o socialismo, segundo Raymond Williams, embora constituída como um movimento contra versões idealistas da experiência humana,

I7 BRECHT, Bertolt. O Caráter Popular..., op. cit., p. 264.

I8 MARX, Karl; ENGELS, Friedrich. A Ideologia Alemã: Crítica da Mais Recente Filosofia Alemã em Seus Representantes Feuerbach, B. Bauer e Stirner, e do Socialismo Alemão em Seus Diferentes Profetas. Tradução de Rubens Enderle, Nélio Schneider, Luciano Cavini Martorano. São Paulo, Boitempo, 2009, p 93-94. 
[...] acabou por ser visto como equivalente ao que ele contestava: uma mera produção, ou a reprodução como um cenário, como um disfarce, para as mesmas histórias antigas idealizadas ou estereotipadas. Na prática, havia coisas que o teatro naturalista, mesmo em seu próprio interesse, não podia realizar. Quanto mais ele encenava a realidade cotidiana, menos ele podia mover-se seja para o pensamento não dito, seja para ação além dos locais selecionados. De forma peculiar, ele foi capturado pela armadilha dos cômodos nos quais as pessoas olhavam para fora pelas janelas ou ouviam gritos vindos das ruas. ${ }^{\text {I9 }}$

Segundo Raymond Williams, o naturalismo burguês trouxe grandes transformações ao incorporar em sua forma o material contemporâneo (em oposição à matéria lendária ou histórica); uma forma da fala cotidiana como fundamento para a linguagem dramática; a extensão social (alargando a caracterização dos personagens que não eram apenas de "nível social elevado"); e uma exclusão de todas as agências sobrenaturais ou metafísicas da ação dramática. As conquistas do naturalismo burguês, como as destacadas pelo crítico, foram incorporadas de maneira cada vez mais ampla, transformando-se em um hábito naturalista. É interessante notar, portanto, que, para Raymond Williams, ao fazer Brecht a distinção entre o teatro épico e o teatro aristotélico, esteja este se referindo ao teatro naturalista e sua implicação empática com o público. De todo modo, fica nítido pela abordagem de Williams que a transformação histórica passa a ser convenção dramática, e é contra essa estabilização do procedimento que podemos compreender as propostas brechtianas.

No estudo empreendido por Peter Szondi em Teoria do Drama Moderno (I880-I950), encontramos a análise de obras sobre a crise da forma dramática nesses termos. Quando o drama passa a ser uma regra de composição, peças mal sucedidas eram equívocos ocasionados por materiais mal escolhidos. O pesquisador irá analisar peças que funcionam na contradição entre a regra dramática e materiais "mal escolhidos" para lançar luz sobre a "antinomia interna” que, em cada obra em particular, estabelece-se entre o "enunciado da forma” e o "enunciado do conteúdo”, fazendo com que, nas palavras de José Antonio Pasta Jr., reciprocamente se historicizem ${ }^{20}$. Segundo Iná Camargo Costa, “com base nas especificações de Diderot, pode-se dizer que a criação do drama correspondeu a uma espécie de expulsão da esfera pública do âmbito do teatro, marca registrada do teatro grego e popular, e mesmo da tragédia neoclássica”2I. Então como poderia ser formalizado um pensamento não dito, uma ação para além dos locais selecionados? Brecht, então, utiliza de uma perspectiva científica, estudando as relações dos homens em cena, fazendo com que a consciência de suas personagens esteja evidenciada a

I9 WILliamS, Raymond. Política do Modernismo. Tradução de André Glaser. São Paulo, Unesp, 20 II, p. II9. 20 SZONDI, Peter. Teoria do Drama Moderno (I880-I950). Tradução de Luiz Sérgio Repa. São Paulo, Cosac Naify, 200I, p. I3.

2I COSTA, Iná. Sinta o Drama. Petrópolis, Vozes, I998, p. 62. 
partir de suas relações concretas, ou seja, restaura a esfera pública mesmo quando o faz de uma perspectiva individual. Dessa forma,

[...] o teatro épico deduz os caracteres das ações porque, ao invés de olhar o indivíduo isoladamente, olha para as grandes organizações de que estes são parte; enquanto o drama se interessa por acontecimentos "naturais", de preferência situados na esfera da vida privada, o teatro épico tem interesse em acontecimentos de interesse público (mesmo os da vida privada), de preferência os que exijam explicação por não serem evidentes nem naturais; enquanto o drama se limita a apresentar seus caracteres em ação, o teatro épico transita dessa apresentação para a representação e desta para o comentário, tudo na mesma cena. ${ }^{22}$

Como vimos anteriormente, o drama burguês passa a ser regra de composição teatral - "expulsando" prólogos e coros, por exemplo - e assim é que seu pressuposto, o amálgama da classe à consciência da personagem, entrevista como “o mundo", é passível de comentário, de suspeita como expressão ideológica para o teatro brechtiano; uma expressão da crise do drama que se dirige à sua superação, se usarmos a categoria de Szondi. Em 30 de março de I947, Brecht anota no Diário de Trabalho que no naturalismo a sociedade é vista como um pedaço da natureza, através de pequenos mundos independentes (família, escola, unidade militar), ao passo que no realismo a sociedade é encarada historicamente, através dos pequenos mundos que se percebem como setores de linha de frente nas grandes lutas ${ }^{23}$.

Como é de fácil conclusão, há política nessas duas formas - drama burguês e teatro épico ${ }^{24}$-, ou, melhor dizendo, em qualquer modelação pois, em última instância, toda obra concretiza uma visão de mundo. Faz pouco a crítica que se satisfaz com esta categorização? Sou levada a considerar que há um teatro político aqui que interessa mais e, para ser coerente com a afirmação, especificar o que isto quer dizer em termos dramatúrgicos ${ }^{25}$.

\section{DRAMAS REPRESENTATIVOS}

O Latão busca tornar inteligível seu processo de trabalho desde sua formação, com a encenação de Ensaio sobre o Latão, estudo cênico baseado em A Compra do Latão, de

\footnotetext{
22 Idem, p 72-73.

23 BRECHT, Bertolt. Diário de Trabalho, Vol. II: América, I94I-I947. Tradução de Reinaldo Guarany e José Laurenio de Melo. Rio de Janeiro, Rocco, 2005, p. 293.

24 Vejamos que para esta breve exposição não faço distinção entre drama (dramaturgia) e teatro (cena) pois isto requereria uma discussão pormenorizada. Para a discussão sobre a contradição entre drama e teatro em Brecht, sugiro a leitura: CARVALHO, Sérgio de. Brecht e a dialética. In: ALMEIDA, Jorge \& BADER, Wolfgang (orgs.). Pensamento Alemão no Século XX: Grandes Protagonistas e Recepção das Obras no Brasil, vol. III. São Paulo, Cosac Naify, 2013.

25 Parte das reflexões deste artigo foi exposta na tese de doutorado Trabalho do Latão, defendida pela autora em novembro de 20I3 na Faculdade de Letras da Universidade Federal do Rio de Janeiro.
} 
Bertolt Brecht. Para o dramaturgo Sérgio de Carvalho, há o empenho em estabelecer uma dramaturgia que explicite o "desacordo entre nossa matéria social e as formas dominantes da representação literária ou teatral”26, sendo assim é necessária uma crítica às "formas consagradas do romance, do drama, da encenação" quando se trata da experiência social brasileira. Para dar legitimidade a sua afirmação, Sérgio recupera, de um lado, as clássicas interpretações sobre a formação brasileira Sérgio Buarque de Holanda, Caio Prado Jr. - problematizando, junto a Francisco de Oliveira, que nossa sociedade se constrói e sofre seu aburguesamento sem a definição de um campo autônomo, ou ainda, numa situação em que há a recorrente anulação do outro; por outro lado se sustenta nos estudos de Bertolt Brecht sobre a ideologia pressuposta nas representações artísticas consagradas que são escamoteadas pelos assuntos supostamente universalizantes, emoldurados pela crítica especializada míope à operação formal, consciente ou não. Antes de buscar determinar o percurso dramatúrgico e cênico do Latão, procuro demonstrar um processo que retira sua força inventiva da consciência sobre o tempo e o lugar que ocupa no sistema teatral brasileiro.

As peças de autoria do grupo - assinadas pelos dramaturgos Sérgio de Carvalho e Márcio Marciano (integrante da equipe até 2007) que dão o tratamento final, ou ainda, responsáveis por sua composição - foram organizadas, no volume Companhia do Latão: 7 Peças, publicação de 2008, em três sessões: I. Imagens do Brasil, com O Nome do Sujeito, A comédia do trabalho e Auto dos bons tratos; II. Cenas da Mercantilização, com O Mercado do Gozo e Visões Siamesas; e III. Releituras, com Ensaio para Danton e Equívocos Colecionados ${ }^{27}$. As peças que compõe "Imagens do Brasil" possuem, se não me engano, um núcleo temático comum (e para efeito desta reflexão incluo $O$ Patrão Cordial como estudo cênico e dramatúrgico inspirado em O Sr. Puntila e Seu Criado Matti): tratam da formação do Brasil, desde tempos da colonização, como em Auto dos Bons Tratos; da formação do comércio nas cidades, como em O Nome do Sujeito; e das relações de trabalho, como em A Comédia do Trabalho e O Patrão Cordial. O assunto, ou a ideia organizadora das peças (incluídas O Mercado do Gozo, Visões Siamesas e Ópera dos Vivos de 20Io), refere-se à crítica anticapitalista assumindo o ponto de vista da classe trabalhadora. Neste ponto compreendo que o Latão produz uma dramaturgia representativa que estuda as condições mesmas de sua formação. Vale sublinhar, então, que sua dramaturgia mantém uma tradição, colocada exemplarmente em "Dialética da Malandragem", por Antonio Candido. Em O Nome do Sujeito, A Comédia do Trabalho, Auto dos Bons Tratos e $O$ patrão cordial, a operação que coloca o homem livre dependente pela dialética da ordem e desordem, contudo, é iluminada pelas situações de trabalho e que, portanto, reposicionam ideologicamente a "experiência de um setor da sociedade”. Se é válido o questionamento de Roberto Schwarz quanto à interpretação do Brasil através da relação ordem e desordem, é um feito para a dramaturgia brasileira contar com exemplos nos quais malandragem e capitalismo

26 CARVALHO, Sérgio. Conversa sobre Dramaturgia Brasileira Contemporânea. In: (org.). Introdução ao Teatro Dialético. São Paulo, Expressão Popular, 2009.

27 CARVALHO, Sérgio; MARCIANO, Márcio (orgs.). Companhia do Latão: 7 peças. São Paulo, Cosac Naify, 2008. 
não se opõem (afinal a epicização do drama auxilia o contorno histórico). A malandragem não é um constructo organizativo de uma experiência de classe, embora a não heroicização, na qual a palavra do trabalhador assuma algo de "interesseiro, inautêntico, contraditório", refreando impulsos populistas, à maneira brechtiana, não seja obliterada pelo horizonte da necessária organização política dos seus setores mais progressistas e que, portanto, evidenciam, pelas situações mesmas em que é colocada, a luta de classes nas quais o "rebaixamento" da experiência do trabalhador só é percebido pelas formas que o capitalismo engendra. Desta questão, podemos retirar dois elementos para análise: a dramaturgia do grupo se faz da síntese entre a consciência da linguagem numa obra artística e a consciência da arte em um sistema capitalista.

Alguns exemplos. Em O Nome do Sujeito há dois prólogos: o primeiro ocorre na rua, tendo como personagens o Bonequeiro e Ludwigo e outro se dá no teatro. Nessa articulação de dois prólogos, a problematização do "mito do palco", como diz o dramaturgo Márcio Marciano, se faz já na rua, sem meias palavras, através do boneco Ludwigo. Interessa ao público apenas um tema universal: o dinheiro. Claro que o lembrete dirigido ao espectador, feito por um boneco irônico, produz riso no público, constituindo uma primeira tensão na dramaturgia. Aparece uma oposição entre os artistas da rua - miseráveis e sem nenhum recurso - e o "templo" teatral, supostamente mais rico, questão que será desmentida pela "falta de luz" no recinto. Ainda é interessante observar que na publicação da peça, a epígrafe de Louis L. Vauthier, diga sobre a miséria do teatro. “Miséria”, em O Nome do Sujeito, cênica, por levar ao palco tão poucos recursos ilusionistas, ricos, entretanto, em tentar produzir uma nova relação com o espectador. Segundo Iná Camargo Costa:

Uma das maiores virtudes de $O$ Nome do Sujeito é aquele enquadramento: enquanto o narrador introduz e especifica o ponto de vista a partir do qual o espetáculo está sendo apresentado. São intervenções que mostram que o espetáculo não tem pretensão de ser o que não é. De início ele assume o ponto de vista da obscuridade e no final tem aquela cena da fotografia em que alguém diz: eu preciso de luz. E aí se apaga tudo. Eu não consigo imaginar maior consciência de ponto de vista. Quando não se participa de um movimento coletivo, o importante é tentar entender o que se passa. E não fazer de conta que está acontecendo alguma coisa que não está. ${ }^{28}$

A partir das considerações de Iná é possível perceber alguns temas do espetáculo: a constituição da classe trabalhadora brasileira, no jogo de favores, junto à própria dimensão do trabalho intelectual, também a serviço do capital. Vejamos, então, as duas questões que rondam esse primeiro experimento autoral da Companhia: uma que diz respeito a sua própria condição de artista, e do teatro em fins da década de I990, e outra, que a reboque da primeira, faz referência ao contexto político e econômico da época estudada. Em busca de tentar compreender

28 A citação foi retirada do site: 〈http://goo.gl/vOMuTI〉. Acesso em: 27 out. 20I3. Segundo informações do site, o texto de Iná Camargo Costa pode ser encontrado em “Por um Teatro Épico”. Vintém, São Paulo, ano 2, n. 3, jul. I999, p I2-I7. 
a formação brasileira, o grupo se aproximou das condições de "formação do sujeito burguês" em meados do século XIX.

Em A Comédia do Trabalho, em termos gerais, o expediente que salta aos olhos é dado pelo prólogo, feito em verso - recorrente na dramaturgia -, que, pelo recurso de uma peça de agitação e propaganda, tem no humor e sátira as marcas fundamentais. Contudo, a comédia de agitprop diz tanto sobre a tragédia da desorganização na vida social brasileira, como também à vida artística. Daí da observação de Sérgio de Carvalho, "este mundo para quem sente é uma tragédia, para quem pensa é uma comédia”"29.

Prólogo a uma tragédia disfarçada

(Entram três atrizes e cantam. Uma delas, a atriz-politizada, carrega um cartaz em que se lê: "Companhia do Latão apresenta A Comédia do Trabalho").

Em Tropélia a fauna é bacana

Na Tropélia das muitas paisagens

Província do sol sempre a pino

Dos homens de infinita voragem

A moeda é o bago tropelino.

$\mathrm{E}$ a bandeira um sol com três vagens.

Quando no horizonte as três naus

Chegaram na costa solar

Encontraram Éden natural

E o melhor bananal para explorar

Porque em Tropélia a vantagem

É que a vida é toda selvagem.

[Narrado.] Em Tropélia, senhores distintos,

$\mathrm{O}$ mercado e a lei, se quiserem

Seguem sempre animalescos instintos

E às vezes se mordem milhões.

Porque em Tropélia a vantagem

É que a vida é toda selvagem.

Atriz-técnica - Então, podemos começar. Estamos prontos.

Atriz-politizada - [Ao público.] Enquanto eles arrumam o cenário, eu preparo o espírito das senhoras e dos senhores para a verdadeira natureza da peça. Depois de meses de ensaio, tentando achar graça do capitalismo financeirizado, tentando rir dos problemas como o desemprego, não tivemos escolha senão fazer uma tragédia: a tragédia do trabalho. Chamamos de comédia apenas para atrair mais público.30

29 O trecho foi retirado de uma entrevista de Sérgio de Carvalho ao Jornal Diário do Pará, em junho de 2004. A entrevista está disponível em 〈http://goo.gl/wWAMyO >.

30 Os textos das peças podem ser encontrados em CARVALHO, Sérgio \& MARCIANO, Márcio. Companhia 
De sensibilidade próxima à Santa Joana dos Matadouros - encenada pelo grupo em I998 -, quanto aos procedimentos formais, A Comédia do Trabalho dá tratamento cômico aos banqueiros e materializa as complexas relações trabalhistas e a grande dificuldade, no presente, de formação de uma consciência de classe.

Realizando mais um estudo, assim como foi O Nome do Sujeito, o Latão representa a dificuldade da organização coletiva da classe trabalhadora. Demonstra a dificuldade de organização política quando mesmo as classes passam por transformações que não "definem" sua posição na luta de classes; não à toa, então, que também estão em cena Mendigos e Pedintes em discussão sobre a desunião da Categoria de miseráveis (!). Se a radicalização do ponto de vista da luta de classes se faz na luta ideológica pela consciência, pelo desvelamento ou dissimulação do caráter classista da sociedade, segundo Lukács ${ }^{3 \mathrm{I}}$, no caso da peça a chave comicamente trágica é o modo de dialogar com o público para ativação dessa consciência.

Já em Auto dos Bons Tratos, o Latão utiliza como material de estudo fatos históricos reais relatados no processo movido contra o donatário Pero do Campo Tourinho. As peças do processo inquisitorial, a apuração das denúncias contra Pero do Campo Tourinho por donatário estarão à disposição do espectador ao longo da peça, não apenas pela representação dos fatos e atos cometidos pelo donatário, mas também pelos diálogos dos demais personagens que narram, a partir de seus pontos de vista, suas ações; assim o espectador, logo na primeira cena, percebe a justificativa do comportamento violento pela fala do juiz Escorcyo, ou de sua reprovação por parte de João de Tiba, traficante de escravos índios que teve entre as suas mercadorias quatro escravos "surrupiados" por Tourinho para o trabalho em seu engenho. Acontece que, como o espectador acompanha, nenhum ato de Tourinho se assemelha a algo bom: ele é extremamente violento com todos, de escravos a homens livres, ou ainda com sua mulher, Ignez, e filha, Leonor. A violência de Tourinho, e de toda a escravidão - que é bom assinalar, posta como instituição que deve seu sentido a uma forma de produção vinculada ao sistema capitalista -, pode ser sintetizada numa cena de seu processo de inquirição na qual é lembrado, pelo padre Bernard de Aujerac, do mando do donatário em cravar uma ferradura nos pés de um índio. O padre pergunta ao ferreiro Douteiro, "me diga, senhor ferreiro, por que tantas crueldades a abominações, por que fazer de um homem com alma, um animal quadrúpede?" a que Douteiro responde: "qual o problema, vigário? Ele serviu de exemplo para que outros não fugissem. E já era uma besta de carga antes da ferradura" ${ }^{2}$. Como é possível observar, a naturalização da violência é dada em chave crítica para a análise do espectador. O pensamento cru do cotidiano é distanciado pela dramaturgia ironicamente que, assemelhado à prática da comédia realista, não registra, entretanto, uma "pintura de costume" que evita situações violentas. A cena em questão - sobre o início do processo de inquirição de Pero

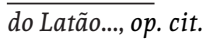

3I LUKÁCS, György. História e Consciência de Classe: Estudos sobre a Dialética Marxista. Tradução de Rodnei Nascimento. São Paulo, Martins Fontes, 2012.

32 CARVALHO, Sérgio \& MARCIANO, Márcio. Companhia do Latão..., op. cit., p. I74. 
do Campo Tourinho - se dá entre Bernard de Aujerac, o inquiridor, o juiz Escorcyo e ferreiro Douteiro, com a participação de João Camelo, homem letrado, poeta e escrivão do processo - sintetiza o argumento da peça (a Igreja disputando com os empreendedores a mão de obra escravizada, nas palavras de Iná Camargo Costa) dada pela sabedoria de Douteiro. Se não me engano, há uma disposição em tornar mais claros os mecanismos de opressão engendrados pelo capitalismo por um discurso proverbial que se esparrama pelo texto dramático.

Assim também o é em O Patrão Cordial, em momentos preciosos da composição dramatúrgica. Após uma surra do patrão, o empregado Descalcinho lamenta-se com sua querida patroinha. Esta por sua vez replica: "passarinho que come pedra sabe o cu que tem". O provérbio popular que transporta a ideia de que "cada um é responsável pelos seus atos” -, é feita como lamento-deboche para aquele -, no caso do trabalhador - que vê os laços de reconhecimento rompidos pela "falta de controle" do superior. A desfaçatez da classe é posta concretamente na cena em que as noivas de Cornélio, o patrão, convidadas por ele para acompanhar o noivado da filha, são expulsas.

CORNÉLIO - Tira elas daqui antes que eu chame a polícia. Saiam!

NOIVA - Olha aqui seu cara de bosta, para que você não se esqueça de mim, eu vou esfregar meu lindo traseiro no chão da sua propriedade, e não vou mentir quando contar para todo mundo, que estive na grande fazenda do senhor Cornélio (senta) e lá sentei-me, porque fui convidada. Agora me levante dessa posição histórica. (A atriz éauxiliada pelas noivas) ${ }^{33}$

"As Histórias Vale-paraibanas" - título da cena seguinte - vão dar conta exatamente de registrar que a "sabedoria é o lado épico da verdade"34. Procedimentos, estes, que possibilitam a imaginação do espectador. Para dizer com Brecht, o conceito de amplitude combina com o realismo.

Com os breves exemplos, não é difícil chegar à conclusão da imensa capacidade de tornar claros, ou seja, conscientes, as expectativas do aparelho teatral e do espectador através do ponto de vista da classe trabalhadora. A prática, antes de ser exclusividade da Companhia do Latão, posto que é recorrente no teatro contemporâneo, acrescenta, entretanto, um repertório de peças com grande alcance literário à dramaturgia brasileira e personagens de falas-modelo à experiência composicional dramatúrgica. Quem esperaria que a filha de um grande proprietário de terras dissesse algo tão "vulgar" como a anedota popular?

33 Registro a contribuição de Elielson Corrêa quanto à observação desta cena.

34 BENJAMIN, Walter. Magia e Técnica, Arte e Política. Tradução de Sérgio Paulo Rouanet. 7. ed. São Paulo, Brasiliense, I994, p. 20I. Em Sr. Puntila e seu Criado Mattu, a fala é feita por Ema. Ao final da cena de Brecht, a Cozinheira canta: "As noivas da Associação chegaram todas/ Para os festejos do noivado/ E o Sr. Puntilla gritou/ Já irritado, àquela hora da manhã: Mas desde quando na tosquia/ As ovelhas têm direito a parte da lã? Só porque vou para cama com vocês/ Uma vez na vida,/ Sou obrigado a lhes dar comida?" BRECHT, Bertolt. Teatro completo, em I2 volumes. Rio de Janeiro, Paz e Terra, I992, p. 80. 
Ou ainda, quem esperaria de uma telefonista a narração em versos de sua própria morte, como em A comédia do trabalho?

Nesta breve apresentação, O Patrão Cordial fornece material de análise para o segundo elemento: a forma cênica modelar em base cômico-realista.

\section{O VALOR DO RISO}

Em 2013 a Companhia do Latão estreou a montagem O Patrão Cordial ${ }^{35}$ - após várias apresentações e estudos cênicos conduzidos desde agosto de 2012 - no Rio de Janeiro no Centro Cultural Banco do Brasil. O roteiro de O Patrão Cordial, segundo o programa da peça, foi escrito a partir da improvisação dos atores e se baseia, também, no estudo do livro Raízes do Brasil de Sérgio Buarque de Holanda. A estrutura dramatúrgica de O Sr. Puntila e Seu Criado Matti, mantida, busca na identificação da propriedade - sugerida pela inversão do O Homem Cordial de Sérgio Buarque de Holanda -; mais próxima, portanto, do próprio Brecht, o motor da cordialidade, que dá o tom às relações de trabalho na realidade brasileira.

A ordem puntiliana, como tratada por Rosenfeld, que afinal é a ordem capitalista, arma a dramaturgia e o mundo por ela proposto, deixando em evidência os mecanismos de manutenção de poder e autoridade que, olhados, então, pela formação brasileira servem à ideia da cordialidade e à dominação pessoal exercida pelo latifundiário. A força individual parece definir a estrutura narrativa - assim como a explicação sociológica -, embora a composição do personagem demonstre uma função organizativa do sistema. O ciclo de dominação exercido por Cornélio (Puntila, em Brecht) se aproxima à construção de uma "comunidade de destino"36 a que os personagens, incluídos os proprietários - Cornélio e sua filha Vidinha estão enredados. Há que se observar, portanto, a maneira como os personagens são apresentados (dramaturgia cênica) de um princípio de reconhecimento da humanidade do Outro operando como um requisito necessário à dominação pessoal. Tal afirmação traz como consequência a problematização do campo da ordem, na peça, exercido por Cornélio, que não "estipula para si mesmo as valorações positivas e negativas”, pela sua própria desintegração psicossociológica, dada pelo auxílio da bebedeira. Retomando a observação de Anatol Rosenfeld, a contradição do senhor é ser reconhecido por quem ele não reconhece, mas agora não em termos idealistas, mas concretos, afinal a humanidade se faz pela função:

VITOR - Eu só vim avisar que não espero mais. (Dá a chave) Não se pode tratar um homem assim.

35 O texto foi cedido gentilmente pela Companhia do Latão. Agradeço a Sérgio de Carvalho e toda a equipe de colaboradores do grupo pelo total acolhimento de solicitações durante meu processo de doutoramento do qual este artigo é fruto.

36 FRANCO, Maria Silvia de Carvalho. Homens Livres na Ordem Escravocrata. São Paulo, Unesp, I997. 
CORNÉLIO - Você falou que é um homem? Agora mesmo disse que era motorista. Admita que eu te peguei numa contradição.

O que nos dirá Puntila no início do século XXI, no Brasil? Se não é o chão compassado da História que se faz a oportunidade da encenação do Latão, é o tema da peça brechtiana que lança luz sobre certos aspectos da sociedade de classes na periferia do capitalismo que nos interessam elucidar em sua estruturação que, pelas questões expostas anteriormente, dizem respeito à própria compreensão do "popular". Do primeiro ponto, a ideia de cordialidade de Sérgio Buarque de Holanda é um constructo explicativo aparente para a compreensão da montagem, embora sua porta de entrada, tanto quanto como explicação sociológica na tentativa de ensaiar (e no que se estabeleceu como explicação da formação do Brasil) uma ética da sociabilidade brasileira; ou, melhor dizendo, de como aprendemos a ler a cordialidade. Não é incomum associar a "cordialidade" a "política de favor e saídas da malandragem", e, para o senso comum, ao "jeitinho brasileiro". Da última operação, há um procedimento ideológico de positivação explicativa que mantém o ethos. Da passagem para o favor e malandragem, em campos estreitos de conhecimento, Roberto Schwarz nos esclareceu de sua função ideológica em As Ideias Fora do Lugar. O que aparece como princípio é consequência. Em outras palavras: a formalização estética organizada pela cordialidade deixa-se ver como "mediação que organiza os dados da ficção e do real" 37 e se constitui como "princípio do mundo imaginário" retirando força para apanhar, dramaticamente, os mecanismos de dominação no Brasil. Dito de outra maneira, a cordialidade é a mediação social e mediação formal. Vejamos como.

Cornélio é um "tipo melancólico": está em evidência o tempo do "milagre econômico" brasileiro; tempo histórico e ficcional que alça à experiência teatral (palco e plateia) questionamentos sobre a sociedade brasileira de hoje. Se há um desagrado em relação à montagem, ele advém de sua recusa em reforçar ou inverter as valorações arraigadas para ambos os lados. Este parece ser um impulso estético diante da tarefa de constituir a cena a partir da proposta cômico-realista.

Na comédia do Latão, de certa forma a relação Puntila-Matti (Cornélio-Vitor) é mantida, e é considerável a complementação cênica, que agora incide também na relação Puntila-Eva, filha de Puntila na igual tentativa de deixar expostos aspectos da sociedade de classes. Vidinha é apresentada, pela encenação, com contornos cênico-dramáticos (apenas a atriz Helena Albergaria porta adereços e complementos cênicos "reais"). Embora com matizes diferenciados e discursos humanizadores que se desfazem pelas ações, ambos estão "em constante contradição consigo mesmo, produzindo na própria pessoa o distanciamento" 38 , como diria Anatol Rosenfeld, exigindo dos atores capacidade crítica daquele que se deixa mostrar como intérprete. A cordialidade em Cornélio, tem na explicação sociológica uma conquista cênica. Já em Vidinha dá-se mais uma volta no parafuso.

37 SCHWARZ, Roberto. Que Horas São: ensaios. São Paulo, Companhia das Letras, I987.

38 ROSENLFELD, Anatol. Brecht e o Teatro Épico. Organização e notas de Nanci Fernandes. São Paulo, Perspectiva, 20I2, p. I35. 
A situação da personagem está em tensão com a matéria social e com isso quero dizer que está em cena o próprio reconhecimento de que a forma dramática é devedora de uma compreensão sobre a autonomia do sujeito, que, entretanto, pela peça, é sempre posta em questão, uma vez que esta ideologia não corresponde às situações concretas da vida, embora seja ela que reivindique esse lugar - lembro o registro cênico diferenciado de Vidinha. Assim, como personagens dramaticamente complementares, o raciocínio frio de Cornélio - pois não são raros os momentos nos quais o latifundiário reconhece a sua função e contraditoriamente alonga-a, por meio do álcool, ao buscar anulá-la - e a emoção profunda de Vidinha revela que tanto os trabalhadores quanto patrões estão em uma situação na qual a humanidade não tem lugar. Se há alguma legitimidade nessa observação, há que se levar em consideração as narrativas dos trabalhadores sobre a vida na pequena cidade no Vale do Paraíba. A espessura dos relatos do mundo do trabalho dá o ponto de vista da montagem. Contudo, não é a estrutura épica que está se acertando ao gosto do público frequentador do teatro, mas o drama burguês que se desmascara em nível formal, posto em tensão com o mundo do trabalho. $O$ mérito da peça, naturalmente de Brecht e do achado cênico do Latão, é não construir um antagonismo absoluto entre personagens ou situações. Como não especular a semelhança da relação de Vidinha e Vitor (e claro de Eva e Matti) à Senhorita Júlia? Posso estar enganada, mas não há no repertório dramatúrgico brasileiro caso semelhante que possa habitar o imaginário do público, tampouco uma cultura de leitura assentada pela literatura dramática. No máximo, foi problematizado por nossa dramaturgia em meados do século XIX e principalmente em princípios do XX a corrupção e hipocrisia da sociedade como tema, mas está muito longe da mentalidade do público resquícios dessa formação via drama, passo que foi dado pela comédia. Mantendo o original, se não há um correlato nacional, porém, pelo menos três encenações do drama de Senhorita Júlia correspondem ao período de estreia de Patrão: A Propósito de Senhorita Julia com direção de Walter Lima Jr.; Senhorita Júlia, com direção de Eduardo Tolentino; e dois anos antes, Júlia, com direção de Christiane Jatahy. A primeira encenação se faz pela transposição temporal, a segunda acentua a participação da personagem Cozinheira Kristin, e a terceira experimenta novas mídias para a encenação teatral, projetando uma gravação prévia e filmando ao vivo os atores. Será esse o imaginário a mobilizar? As semelhanças das encenações, pois os procedimentos estéticos divergentes os aproximam da função dramática, estarão em juízo no Patrão?

A Vidinha sugere a relação que pode se estabelecer com o espectador caso haja alguma identificação deste com a personagem. No início da peça, há a seguinte narração: "No Brasil não foi formado o individuo moderno. Mas só quando existe diálogo entre indivíduos é que a desigualdade aparece como resultado da dominação de classe".

É preciso determinar, junto ao rendimento da peça, um sentido para a narração inicial. Mesmo quando Cornélio, a exemplo de Puntila, utiliza a embriaguez como forma de "escapar" de sua função como proprietário, operando a conhecida "cordialidade", a violência da estrutura capitalista está à mostra nas situações dos personagens. As relações entre patrões e empregados ganham completa 
demonstração na encenação, que também se desdobra com os demais personagens da peça: empregados na fazenda de Cornélio e trabalhadores livres que o servem em outros ambientes, como no bar ou no Mercado de Trabalhadores.

A situação fica um pouco mais complicada quando se observam as relações entre pai e filha, que se dão, também, no eixo da propriedade. O sentimentalismo de Vidinha, que não está interessada em seu noivo Hélio, mas no motorista Vitor é uma das chaves para perceber o estrago das relações de propriedade que se faz em âmbito individual. Na cena 5, intitulada: “Na Fazenda, a Necessidade do Escândalo", muito do efeito hipnótico do teatro cômico (e aqui estamos no terreno da paródia) enreda o espectador, embora a cena comece com uma narração de Vivi: “Um aposentado grego de 77 anos se suicidou ontem nas proximidades do parlamento do país, dizendo ser esse o único fim digno possível para ele, numa Grécia que atravessa severa crise. Não quero deixar dívidas para os meus filhos - gritou segundo testemunhas, antes de atirar na própria cabeça, debaixo de uma árvore. Escreveu num bilhete: antes de começar a procurar comida no lixo".

A narração é entrecortada com a chegada de Luís Carlos, ex-trabalhador, demitido por ser comunista e que retorna à fazenda no momento "cordial" de Cornélio. A "imagem" do aposentado grego vai se desfazendo na medida em que a cena avança e tenta ser "reativada" pela apresentação de outras relações da narrativa: nela acompanhamos, via narração, a surra que Descalcinho leva do patrão, que estando sóbrio desfaz os acordos prévios com o novo trabalhador, ou, ainda, acusa Vitor de roubo, por este estar com sua carteira dada a ele pelo patrão, quando ébrio. Vidinha observa a cena e pergunta a Vitor:

VIVI - Por que não se defendeu? Todo mundo sabe que quando papai bebe dá a carteira pros outros, para não ter que mexer com dinheiro.

VITOR - Os patrões não gostam de quem se defende.

VIVI - Santinho do pau oco. Já me bastam os meus problemas.

VITOR - O noivado é amanhã, né? Bonito.

VIVI - Quem te pediu opinião!

VITOR - É bom, quando a noiva e o noivo tem afinidade.

VIVI - O Hélio é uma pessoa sensacional, o problema é ser mulher dele.

VITOR - Quem escolheu foi a senhora.

VIVI - É, uma coisa que nem todos têm: livre arbítrio, (Vinheta musical, todos ficam de pé) sabe o que quer dizer: capacidade de decidir a própria sorte. Eu sempre tive, papai me disse que, se eu quiser me caso com qualquer um, até com você. (Vinheta musical. 
Dançam pelo espaço e se posicionam) Mas não podemos romper o noivado. Papai não é homem de voltar atrás com a palavra. “o pico do Itatiaia pode...”Ah é isso.

VITOR - É, uma boa encrenca.

VIVI - Não sei por que eu me abro em assuntos tão íntimos.

VITOR - Isso de se abrir demonstra humanidade.

VIVI - O que eu faço, você pode me ajudar. (Vivi se joga aos pés de Vitor)

Foco para Descalcinho e Hina que comentam a cena

DESCALCINHO - Tudo é tão delicado, me ajuda? E ele disse: mostre ao noivinho que você é uma mulher perdida, que trata um empregado como eu com uma intimidade perigosa.

HINA - Eles se beijaram?

DESCALCINHO - Os dois entraram juntos no banheiro. (Casal corre para o banheiro ao fundo da cena. Descalcinho olha pela fresta)

VIVI - ... Uma mulher perdida, uma ordinária, uma vagabunda?

VITOR - É preciso organizar o escândalo.

VIVI - Tudo bem, eu topo. Mas não abusa de mim. (Ele mostra o baralho) Pra que o baralho?

VITOR - (Embaralha as cartas) A coisa pode demorar, melhor manter as mãos ocupadas.

VIVI - Eles nunca vão acreditar que estamos fazendo essas porcarias a essa hora do dia.

VITOR - Ah, vão, é só gemer bem alto. Pode cortar.

Acompanhamos nessa cena como a violência das relações de trabalho vão deixando o terreno para a construção do escândalo, que, do ponto de vista dramatúrgico coincide com a construção da ação cômica. Nenhum dos personagens coagidos e violentados pelo patrão está em registro sentimentalizável, ao passo que quando começa a falar de sua infeliz vida, Vivi começa a conduzir a história e o espectador é enredado na ficção esperando a solução do escândalo: se o noivo ficará ofendido ou não, se desmanchará o noivado ou não. É claro que no encadeamento da cena, pela emoção profunda de Vidinha na narração, a forma cômica se constitua 
como um princípio estruturador da dramaturgia cênica e marca um registro desmistificador do drama burguês, fazendo com que sua utilização localizada não aqueça o antagonismo para a estética conhecida do espectador. A cena no banheiro, deliciosa, aponta para o grotesco: "uma forma de estilização baseada no contraste e na dissonância que conduz àquela mescla "estranha", junção "desautomatizante", e que leva o espectador a assumir uma postura crítica diante daquilo que ocorre no palco39. Se todo o registro da peça repousasse sobre esse código, entretanto, não passaria de uma “puta que vende um 'efeito' nu, e que por isso é bem paga, já que seus clientes são impotentes"ło, o que é muito comum no teatro brasileiro contemporâneo. O antagonismo modelar do gênero - drama e comédia - não comparece em seu efeito ideológico, o que faz com que este seja percebido em termos concretos.

Em O Patrão Cordial, Vidinha - em cenas com o motorista Vitor - é o recurso que permite a interpenetração do estudo épico-dramático em uma unidade contraditória de princípio dramatúrgico-cênico e ideológico, no qual a luta de classes fica explícita pela ameaça de que o empregado compartilhe, ou "barbaramente invada" o espaço do patrão, derrubando qualquer véu ideológico, como posto pela cordialidade e em consequência formal, pela ótica dramático-burguesa. E o recurso dramatúrgicocênico presente em O Sr. Puntila e o Seu Criado Matti, mantido pelo Latão em $O$ Patrão Cordial, é muito potente: quando de fato se avizinha a intimidade, o tapa dado por Vitor na bunda de Vivi após uma cena na qual ela tenta convencê-lo de que é um "bom partido" para o motorista, novamente retoma o eixo da propriedade através do "gestus"4I ("VIVI - não te autorizo a me encostar um dedo"). O tema da propriedade é levado até a última cena, numa sensibilidade derramada de Cornélio (muito próxima à cena do monte Hatelma em Brecht, que, segundo Anatol Rosenfel, dá a medida da suspeita do amor à natureza). O mundo generoso de Brecht, tal como pressentido por Anatol Rosenfeld, é pressentido ambiguamente na peça do Latão, por isso da observação final de Luís Carlos: "Quando virá o tempo em que um realismo do tipo que a dialética poderia viabilizar será realmente possível? Temos a todo instante que idealizar, já que a todo instante temos de declarar nossa posição, e, portanto, fazer propaganda".

Com o que foi exposto anteriormente, devo apresentar uma ressalva a esta fala retirada dos diários de Brecht. Circunscrita ao contexto da peça em questão - e que a ela não seria justa -, não me parece, em sentido restrito, pertinente. Em uma trajetória de pelo menos dezesseis anos, a propaganda, se não me engano, faz referência a um princípio da dialética: o salto da quantidade para a qualidade. Se a sabedoria contida nas peças apresenta uma aplicabilidade, esta espera uma forma da vida.

39 CAVALIERE, Arlete. Teatro Russo: Percurso para um Estudo da Paródia e do Grotesco. São Paulo, Humanitas, 2009 , p. 26.

40 BRECHT, Bertolt. Diário de Trabalho, Vol. II..., op. cit., p. 22 I.

4I Segundo Fredric Jameson, O gestus envolve claramente todo um processo no qual um ato específico - na verdade, um fato particular, situado no tempo e no espaço vinculado a indivíduos concretos específicos - é assim identificado e renomeado, associado a um tipo mais amplo e mais abstrato de ação em geral, e transformado em algo exemplar. JAMESON, Fredric. O Método Brecht. Tradução de Maria Sílvia Betti. Petrópolis, Vozes, I999, p. I43. 


\section{UM EPÍLOGO}

Quando O Patrão Cordial estreou, as críticas especializadas não foram generosas. A peça seria anacrônica, museológica, ou, ainda, reforçaria um conhecimento prévio do público quanto à explicação de que o "homem cordial é uma balela frente à divisão da sociedade em classes" ${ }^{\prime 2}$. Como busquei analisar, esses termos coexistem, sendo a cordialidade uma possibilidade de expressão da luta de classes e um recurso formal dos mais consequentes. A peça, nesse sentido, apresenta, se não me engano, rendimento ainda maior se analisada pela teoria teatral e dramatúrgica contemporânea.

Em Léxico do drama moderno e contemporâneo, Jean-Pierre Sarrazac apresenta questões interessantes para se pensar a dramaturgia a partir do questionamento da "crise do drama”. Para ele, Szondi se entregou "às tendências teleológicas da época, sugerindo a "forma épica do teatro" como superação ou uma espécie de saída da crise inaugurada na época do naturalismo". Nos termos de Sarrazac:

No momento em que marxismo e psicanálise partilham a interpretação e a transformação das relações entre o homem e o mundo, o universo dramático - que se impôs, grosso modo, do Renascimento ao século XIX, essa esfera das "relações interpessoais" em que drama significa "acontecimento interpessoal no presente" - não é mais válido. Submetida à pressão, à invasão de novos conteúdos e novos temas (girando todos mais ou menos em torno dessa separação, psicológica, moral, social, metafísica etc., do homem com o mundo), a forma dramática - na tradição aristotélico-hegeliana de um conflito interpessoal resolvendo-se como uma catástrofe - começa a rachar em toda parte. A teoria de Szondi nos ensina que a separação por nós evocada traduz-se, no domínio do teatro, na separação do sujeito e do objeto: essa síntese dialética do objetivo (o épico) e do subjetivo (o lírico) que operava o estilo dramático - interioridade exteriorizada, exterioridade interiorizada - não é mais possível. A partir desse momento, universo objetivo e universo subjetivo não coincidem mais, achando-se reduzidos a um confronto dos mais problemáticos. Cabe aos dramaturgos administrar esse divórcio na medida do possível. [...] Para Szondi, a crise se explica por uma espécie de luta histórica em que o Novo, a saber, o épico, deve no fim triunfar sobre o Antigo, isto é, o dramático. 43

Ainda que não concorde com a observação de que Szondi conforme-se a tendências teleológicas, é proveitosa a observação de Sarrazac quanto a critica feita por Sartre e Barthes ao impasse do marxismo e a expressão da subjetividade no teatro (para o lugar e época em que é feita me parece injusta; para o aqui e agora é pertinente). Não se trata, contudo, como quer Sarrazac, de buscar uma dramaturgia que conjugue, sem subordinação, o regime da cena dramática e do quadro épico-lírico. A produtividade da dramaturgia e da cena materialista-dialética não

42 Mario Sergio Conti escreveu em I5 de novembro de 2013 para o jornal Folha de S. Paulo.

43 SARRAZAC, Jean-Pierre. Léxico do Drama Moderno e Contemporâneo. Tradução de André Telles. São Paulo, Cosac Naify, 20I2, p 23-24. 
advém de "regimes de cena". A força do teatro épico-dialético pulsa pela contradição que nos termos atuais está, também, no desajuste entre a expectativa do leitor/ público e do texto/palco.

\section{SOBRE A AUTORA}

PRISCila matsunaga Professora do Programa de Pósgraduação em Ciência da Literatura, doutora em Ciência da Literatura pela Faculdade de Letras da Universidade Federal do Rio de Janeiro, mestre em Educação (Unicamp) e bacharel em Psicologia (Unimep).

E-mail: primatsunaga@gmail.com

\section{REFERÊNCIAS BIBLIOGRÁFICAS}

BENJAMIN, Walter. Magia e Técnica, Arte e Política. Tradução de Sérgio Paulo Rouanet. São Paulo, Brasiliense.

. Tentativas sobre Brecht. Prólogo y traducción Jesus Aguirre. Madrid, Taurus, I985.

BOAL, Augusto. Técnicas Latino-americanas de Teatro Popular. São Paulo, Hucitec, I979.

BRECHT, Bertolt. Diário de Trabalho, Vol. I: I938-I94I. Tradução de Reinaldo Guarany e José Laurenio de Melo. Rio de Janeiro, Rocco, 2002.

. Diário de Trabalho, Vol. II: América, I94I-I947. Tradução de Reinaldo Guarany e José Laurenio de Melo. Rio de Janeiro, Rocco, 2005.

. Escritos sobre Teatro, Vol. II. Selección de Jorge Hacker. Traducción de Nélida Mendilaharzu de Machain. Buenos Aires, Nueva Vision, I970

. Escritos sobre Teatro, Vol. II. Selección de Jorge Hacker. Traducción de Nélida Mendilaharzu de Machain. Buenos Aires, Nueva Vision, I970.

. Estudos sobre Teatro. Tradução de Flama Pais Brandão. Rio de Janeiro, Nova Fronteira, 2005. . O Caráter Popular da Arte e o Realismo. In: MACHADO, Carlos Eduardo. Um Capítulo da História da Modernidade Estética: Debate sobre o Expressionismo. São Paulo: Unesp, I998.

CANDIDO, Antonio. Dialética da Malandragem. In: . O Discurso e a Cidade. Rio de Janeiro, Ouro sobre Azul, 20Io.

CARVALHO, Sérgio de. Brecht e a dialética. In: ALMEIDA, Jorge \& BADER, Wolfgang (orgs.). Pensamento Alemão no Século XX: Grandes Protagonistas e Recepção das Obras no Brasil, vol. III. São Paulo, Cosac Naify, 2013.

. Conversa sobre Dramaturgia Brasileira Contemporânea. In: . (org.). Introdução ao Teatro Dialético. São Paulo, Expressão Popular, 2009. . ;MARCIANO, Márcio (orgs.). Companhia do Latão: 7 peças. São Paulo, Cosac Naify, 2008.

CAVAliERE, Arlete. Teatro Russo: Percurso para um Estudo da Paródia e do Grotesco. São Paulo, Humanitas, 2009.

CONTI, Mario Sergio. O Patrão Cordial e a Vida Curta. Folha de S. Paulo, I5 nov. 2013.

COSTA, Iná Camargo. Por um Teatro Épico. Vintém, São Paulo, ano 2, n. 3, jul. I999. 
Sinta o Drama. Petrópolis, Vozes, I998.

FRANCO, Maria Silvia de Carvalho. Homens Livres na Ordem Escravocrata. São Paulo, Unesp, I997. JAMESON, Fredric. O Método Brecht. Tradução de Maria Sílvia Betti. Petrópolis, Vozes, I999.

LUKÁCS, György. História e Consciência de Classe: Estudos sobre a Dialética Marxista. Tradução de Rodnei Nascimento. São Paulo, Martins Fontes, 2012.

MACHADO, Carlos Eduardo Jordão. Um capítulo da História da Modernidade Estética: Debate sobre o Expressionismo. São Paulo, Unesp, I998.

MARX, Karl \& ENGELS, Friedrich. A Ideologia Alemã: Crítica da Mais Recente Filosofia Alemã em Seus Representantes Feuerbach, B. Bauer e Stirner, e do Socialismo Alemão em Seus Diferentes Profetas. Tradução de Rubens Enderle, Nélio Schneider, Luciano Cavini Martorano. São Paulo, Boitempo, 2009.

MATSUNAGA, Priscila Saemi. Trabalho do Latão. Tese de doutorado, Rio de Janeiro, Universidade Federal do Rio de Janeio, 2013.

MERKEL, Ulrich (org.). Teatro e Política: Poesias e Peças do Expressionismo Alemão. Rio de Janeiro, Paz e Terra/Instituto Cultural Brasil-Alemanha, I983.

PEIXOTO, Fernando. Brecht Vida e Obra. Rio de Janeiro, Paz e Terra.

RABETTI, Maria de Lourdes. Teatro e Comicidades 2: Modos de Produção do Teatro Ligeiro Carioca. Rio de Janeiro, 7Letras, 2007.

ROSENLFELD, Anatol. Brecht e o Teatro Épico. Organização e notas de Nanci Fernandes. São Paulo, Perspectiva, 2012.

SARRAZAC, Jean-Pierre. Léxico do Drama Moderno e Contemporâneo. Tradução de André Telles. São Paulo, Cosac Naify, 2012.

SCHWARZ, Roberto. Que Horas São: Ensaios. São Paulo, Companhia das Letras, I987.

SZONDI, Peter. Teoria do Drama Moderno (I880-I950). Tradução de Luiz Sérgio Repa. São Paulo, Cosac Naify, 200I.

WILliAMS, Raymond. Política do Modernismo. Tradução de André Glaser. São Paulo, Unesp, $20 I I$. 